\title{
СОЦІАЛЬНЕ ЗАБЕЗПЕЧЕННЯ ВОЇНІВ-«АФГАНЦІВ» I СІМЕЙ ЗАГИБЛИХ ВІЙСЬКОВОСЛУЖБОВЦІВ В УКРАЇНІ У 1980-х рр.
}

\author{
Дмитро Островик \\ Університет Григорія Сковороди в Переяславі (Переяслав, Україна) \\ e-mail: dima_ostrovyk@ukr.net \\ ORCID: https://orcid.org/0000-0001-7435-7035
}

Стаття присвячена вивченню реалізації радянської державної політики щодо соціального забезпечення воїнів-«афганців» і сімей загиблих військовослужбовців в УРСР упродовж 1980-х рр. Висвітлено такі напрямки державної підтримки як покращення матеріально-побутових умов «афганців», що зазнали інвалідності та сімей загиблих військовослужбовців (виділення житла, надання матеріальної допомоги у будівництві або ремонті житлових і господарських приміщень); забезпечення засобами пересування - виділення автотранспорту; телефонізацію помешкань; пенсійне забезпечення «афганців» 3 інвалідністю, членів родин загиблих воїнів, пенсійні виплати «на дітей» загиблих військових; медичне забезпечення - диспансеризацію, санаторно-курортне оздоровлення «афганців» з інвалідністю; прикріплення вказаних категорій осіб для продовольчого та побутового обслуговування до салонів-магазинів для «інвалідів ВВВ», забезпечення паливом, матеріальну допомогу сім'ям загиблих «афганців» щодо встановлення надгробних пам'ятників воїнам тощо.

Ключові слова: державна політика, соціальне забезпечення, воїни-«афганці», сім'ї загиблих

Проблематика регламентації та реалізації радянської державної політики у цілому та соціального забезпечення зокрема щодо воїнів-«афганців» і сімей загиблих військовослужбовців є малодослідженою у вітчизняній історіографії. Між тим, іiї студіювання видається актуальним у розрізі викликів сучасного українського соціуму, чільне місце серед яких належить консолідації української нації у протистоянні з ворогом, розбудові війська та впровадженню соціальної політики, спрямованої на створення гідних умов реабілітації, соціальної адаптації, самореалізації ветеранів «АТ0/ООС», підтримки їхніх сімей. Разом із цим, потребує вдосконалення система соціального забезпечення таких категорій, як «учасники війни», «інваліди війни», «учасники бойових дій», що має спонукати до дослідницьких пошуків і вирішення проблем у даній сфері.

Наявні розвідки здебільшого репрезентують різнопланові аспекти «афганського» руху досліджуваного періоду: питання соціальної активності воїнів-«афганців» у контексті взаємовідносин партійних, комсомольських інституцій з різними об'єднаннями молоді, у тому числі - «афганськими» осередками (праці М. Багмета, С. Сороки, А. Костирі, К. Левчука1). Ширші тематичні та хронологічні рамки заро-

\footnotetext{
1 Багмет М., Сорока С. Комсомол і неформальні об'єднання України в період «перебудови» // Політичний менеджмент. 2006. № 5. С. 164-181; Костиря А. Историография, источниковедение, библиография спецоперации СССР в Афганистане (1979-1989 гг.). Київ, 2008. С. 331-333; Левчук К. Громадські організації України: створення та діяльність (1985-1996). Вінниця, 2009. С. 81, 86, 148, 159, 160; Левчук К. Створення та основні напрямки діяльності Української спілки ветеранів Аф-
} 
дження і розвитку «афганського» руху в УРСР, соціальних наслідків війни репрезентовані у монографії С. Червонописького². Питання соціалізації «афганців» в українському суспільстві крізь призму еволюції їхнього соціального статусу порушувала І. Шинкаренко3. Тема трансформації державної політики відносно «афганців», проблем ії реалізації на місцях, а також рефлексій «молодих ветеранів» щодо окремих аспектів соціальної адаптації у реаліях радянського суспільства висвітлювались у публікаціях Д. Островика4. Динаміку правового статусу учасників бойових дій в Афганістані у контексті радянської соціальної політики досліджувала російська соціологиня Н. Данілова5.

У вказаних дослідженнях представлена інформація щодо законодавчого закріплення державної підтримки щодо «афганців» і сімей загиблих військовослужбовців, однак відсутній аналіз різних видів забезпечення вказаних категорій, які перебували на контролі партійних органів, та як реалізовувалася державна підтримка щодо них на місцях. Тому видається важливим залучення до наукового обігу партійних матеріалів, зокрема, центральних та обласних архівів, що містять інформацію з досліджуваного питання.

Мета статті - прослідкувати складові соціального забезпечення щодо воїнів«афганців» і сімей загиблих військовослужбовців та їхню реалізацію впродовж 1980-х рр. в Україні.

Учасник бойових дій і дослідник «афганського» руху в Україні С. Червонописький характеризував закріплені за «афганцями» та сім'ями загиблих у 1980-х рр. такі напрямки соціального захисту як фінансове забезпечення, зокрема, - призначення пенсій за «більш високими нормами», медичне - безкоштовне надання протезноортопедичних виробів, позачергове обслуговування у лікувально-профілактичних закладах, обов'язкова щорічна диспансеризація; надання житла, транспортних засобів, пільг і переваг щодо житлово-комунальних питань, матеріально-побутового обслуговування, побутової допомоги «афганцям» та їхнім сім'ям6.

Початок формування «афганської» законодавчо-нормативної бази дослідники вбачають у прийнятті 17 січня 1983 р. спільної Постанови ЦК КПРС та Ради Міністрів СРСР «Про пільги військовослужбовцям, робочим та службовцям, що знаходяться у складі обмеженого контингенту радянських військ на території Демократичної республіки Афганістан, та їх сім'ям», котра «дискурсивно легітимізувала» участь радянських військ у бойових діях і закріпила права учасників та зо-

ганістану (1985-2000рр.) // Гілея: науковий вісник. 2016. Вип. 105. С. 84-87.

2 Червонописький С.В. Політичні та соціальні наслідки для України спецоперації СРСР в Афганістані 1979-1989 років і роль УСВА в їх подоланні. Київ, 2008. С. 17-41, 43-79.

3 Шинкаренко І. Еволюція соціального статусу воїнів-інтернаціоналістів в українському суспільстві // Філософсько-педагогічні аспекти формування свідомості технічної інтелігенції: Матеріали IV регіональної науково-практичної конференції (11 березня 2010 р.). Красноармійськ, 2010. C. 187-193.

4 Островик Д. Проблеми адаптації воїнів-«афганців» в умовах трансформаційних процесів у радянському соціумі 1980-х pp. // Наукові записки з української історії: Збірник наукових статей (Переяслав-Хмельницький). 2018. Вип. 44. С. 88-98; Островик Д. Трансформація державної політики радянської влади щодо воїнів-«афганців» в Україні 1979-1991рр. // Військово-історичний меридіан: електронний науковий фаховий журнал. 2019. № 1 (23). C. 150-170. URL: https://vim.gov.ua/pages/_journal_files/23.05.2019/pdf/VIM_23_2019-150-170.pdf

5 Данилова Н.Ю. Военнослужащие, воины-интернационалисты, ветераны: динамика правового статуса // Социологические исследования. 2001. № 10. С. 77-84.

6 Червонописький С.В. Вказ. пр. С. 41. 
бов’язання держави щодо вказаних категорій осіб. Однак вона була опублікована лише у 1988 p. $^{7}$

Між тим, регламентація окремих питань щодо підтримки сімей загиблих воїнів зафіксована раніше. Зокрема, як приклад можемо навести розгляд виконкомом Київської міськради народних депутатів у жовтні та грудні 1981 р. питання «надання допомоги сім'ям загиблих за кордоном радянських громадян», про що інформувався ЦК КПУ8. Так, рішення виконкому від 26 жовтня 1981 р. зобов'язувало виконкоми районних рад виділяти кошти (до 1000 крб.) на виготовлення і встановлення надгробних пам'ятників для загиблих військовослужбовців. Рішенням цього ж органу від 17 грудня 1981 р. визначався порядок проведення похорону, виготовлення та встановлення пам'ятників, а також було встановлено зобов'язання для виконкомів районних рад щодо відшкодування витрат (до 1000 крб.) сім'ям, котрі встановили пам'ятники на могилах «загиблих за кордоном після 1 грудня 1979 р.». Також Головне управління торгівлі зобов'язувалося прикріпити вказані сім'ї на продовольче забезпечення до магазинів для інвалідів Великої вітчизняної війни9.

Після прийняття Постанови ЦК КПРС та Ради Міністрів СРСР 17 січня 1983 р. 3 боку партійних осередків прослідковується контроль питань щодо матеріальнопобутового забезпечення воїнів, які отримали поранення, зазнали інвалідності «при виконанні інтернаціонального обов'язку та сімей загиблих військовослужбовців». Зокрема, такі відомості зафіксовані у повідомленні ЦК КПУ до ЦК КПРС від 15 березня 1984 р., в якому зазначалось про обстеження умов життя, праці та побуту вказаних категорій і задовільнені їхніх «побажань» у питаннях працевлаштування, направлення на навчання, покращення медичного, торгового, побутового обслуговування, забезпечення засобами пересування, паливом, будматеріалами, сприяння у ремонті житла, прийому дітей у дошкільні заклади тощо ${ }^{10}$. Окрім цього, вказувалося про «план» покращення житлових умов протягом «двох-трьох місяців» для 212 «сімей інвалідів і загиблих воїнів», задоволенні прохань у встановленні 116 телефонів, виділенні 35 автомобілів, пришвидшення встановлення пам'ятників на могилах загиблих воїнів, залучення демобілізованих воїнів, «з урахуванням їхніх побажань, до трудової та суспільної діяльності», встановлення над воїнами-інвалідами та пораненими у шпиталях і сім'ями загиблих воїнів шефства трудових колективів, комсомольських та піонерських організацій 11.

Відомості щодо наслідків обстеження та заходів задля поліпшення матеріально-побутових умов «афганців», що зазнали інвалідності та сімей загиблих військовослужбовців фіксуємо у регіонах. Так, районні та міські комітети звітували про створення комісій, до складу яких входили представники їхніх апаратів, виконавчих комітетів, відділів соціального забезпечення та які займались даною роботою і звітували про прийняті заходи.

Зокрема, така інформація представлена у контрольних матеріалах з виконання постанов Волинського обкому КПУ, котра подавалася міськкомами та райкомами протягом вересня-жовтня 1984 р. Так, на місцях «звітували»: Володимир-

\footnotetext{
7 Данилова Н.Ю. Указ. раб. С. 79; Костиря А. Указ. раб. С. 23; Червонописький С.В. Вказ. пр. С. 40. 8 Центральний державний архів громадських об'єднань України (далі - ЦДАГО України). Ф.1. Оп. 25. Спр. 2250. Арк. 1.

9 Ibidem.

10 ЦДАГО України. Ф. 1. Оп. 25. Спр. 2696. Арк. 15.

11 Ibid. Арк. 15-16.
} 
Волинський міськком - поліпшення житлових умов інваліду РА з дружиною - надання однокімнатної облаштованої квартири; надання воїну з сім'єю трикімнатної квартири; підключення у батьківський будинок телефону, поставлення на чергу для отримання автомобіля; Луцький міськком - забезпечення квартирними телефонами, вирішення питань працевлаштування з урахуванням стану здоров'я, поставлення на облік у лікувальних закладах, виділення санаторно-курортних путівок; Ковельський міськком - надання 4 особам дворазової матеріальної допомоги, виділення 1 «афганцю» путівки на санаторно-курортне лікування та «виділення для придбання» автомашини, закріплення шефських організацій; виділення 2 особам житлової площі, перебування 2 осіб на пільговій черзі на отримання житла, закріплення «афганців» за салоном-магазином для отримання продуктів харчування; виділення інваліду II групи з дружиною та дочкою для ремонту власного будинку 80 листів шиферу, 0,5 т. цементу, продаж райспоживспілкою 5 ц. картоплі, обмін ділянки городу та виділення путівки на санаторно-курортне лікування; Нововолинський міськком - поставлення на квартирний облік на підприємствах на пільговій основі 9 «афганців», що потребували покращення житлових умов; отримання військовослужбовцями, що проходили службу в ДРА (Демократичній Республіці Афганістан - Aвт.) «посвідчення на пільги» та прикріплення до магазину для отримання продуктів підвищеного попиту; Горохівський райком - виділення квартири та проведення ремонту на суму десять тисяч карбованців (!); іншу особу цієї категорії - «взято на облік, надано необхідну допомогу»; 3 осіб, за їх проханням, направлено на обстеження та лікування в районну лікарню; Ківерцівський райком - проведено «біжучий ремонт» житлового будинку, «з дозволу райвиконкому утримує коня» (!), виділення легкового автомобілю «Запорожець»; забезпечення 2 осіб квартирами в Луцьку; Луцький райком - для ремонту будинку виділено шифер, цеглу, поставлено на чергу для отримання квартири, забезпечення паливом; Маневицький райком - направлення «афганця» 3 категорії інвалід РА на «навчання по путівці комсомолу» в інститут; Ратнівський райком - виділення «афганцю» для ремонту власного будинку $8 \mathrm{~m}^{3}$ будівельних матеріалів, збільшення розміру пенсії на тридцять карбованців (з першого липня 1984 р. - становила 97 крб.), отримання ним автомобіля, закріплення для медичного обслуговування до лікарні, для торговельного - до сільпо; іншому інваліду РА ІІ групи - підключення телефону та збільшення розміру пенсії до дев'яносто семи карбованців; Старовижівський райком - призначення пенсії інваліду III групи (2 серпня 1984 р.) у розмірі 40 крб. 12

Відомості щодо цієї роботи з даними категоріями громадян подавали також виконком Обласної ради, профспілка, обком ЛКСМ України, обласний соцзабез та управління охорони здоров'я. Згідно їхніх даних, 5 «інвалідам РА» було визначено забезпечення спецавтотранспортом (3 надано, 2 - планувалося видати після отримання водійських посвідчень); 4 - виділено путівки у санаторії; 3 - встановлено квартирні телефони («де дозволяли технічні можливості»); 15 «афганцям» проведені перерахунки пенсій. Обласний комсомольський комітет звітував, що станом на 10 жовтня 1984 р. в області проживало 29 воїнів запасу, що отримали поранення та контузії «при виконанні інтернаціонального обов'язку» та 30 осіб загинуло.

12 Державний архів Волинської області (далі - ДАВО). Ф. 1. Оп. 17. Спр. 684. Арк. 3, 4, 6, 7, 8, 9, 10, $12,16,17,20,28,32$. 
Зазначалося про виділення старшому сержанту запасу ділянки городу, двох свиней, бензопили «Дружба», завезення дров і 5 ц. картоплі; проведення ремонту квартири інваліду III групи; сприяння у працевлаштуванні інваліду I групи. Управління охорони здоров'я звітувало про прирівнення «інвалідів РА» (у даному випадку тих, хто отримав інвалідність, «виконуючи інтернаціональний обов'язок») до «інвалідів Вітчизняної війни» (очевидно - учасників «Великої вітчизняної війни») та повідомляло, що станом на 28 вересня 1984 р. 21 особа була оздоровлена амбулаторно, 9 пройшли лікування у відділеннях обласного шпиталю, 2 - у республіканському шпиталі «інвалідів Вітчизняної війни», протезовано 3 особи. Управління соцзабезу інформувало про пенсійне забезпечення 28 інвалідів РА та 8 сімей загиблих воїнів ${ }^{13}$.

Щодо поліпшення матеріально-побутових умов сімей загиблих військовослужбовців райкоми звітували про: виділення сім'ї загиблого воїна, на прохання матері, зерна, добрив, надання одноразової грошової допомоги по лінії райсоцбезу; встановлення телефону, радіоточки, а також надання грошової допомоги та призначення пенсії «місцевого значення» матері іншого загиблого; виділення будинку сім'ї «трагічно загиблого» інваліда II групи; виділення батькам воїна 2 м $^{3}$ дощок для ремонту підлоги; збільшення для 4 сімей розмірів пенсійного забезпечення, виділення кормів для худоби, поширення пільг при оплаті комунальних послуг для 3 сімей; виділення для сімей 2000 цеглин, 1 т. цементу, 60 листів шиферу та 15 листів тирсоплити відповідно; виділення «цегли, шиферу і лісу» для закінчення будівництва будинку та хліва, призначення пенсійного забезпечення для батька у розмірі 45 крб. - по втраті годувальника; виділення для потреб сім'ї 50 листів шиферу та м ${ }^{3}$ «лісу», забезпечення паливом, встановлення групи інвалідності для матері воїна, виділення 50 листів шиферу, 1,5 т. цементу, 6000 цеглин, кормів; надання одноразової грошової допомоги сім'ї (100 крб.); надання сім'ї загиблого «облаштованої квартири»; призначення пенсійного забезпечення для батька «за загиблого сина» (40 крб. 80 коп.), виділення для нього протягом 1984 р. м ріалу, двох центнерів цементу, п’яти кубічних метрів дров та одноразової грошової допомоги (20 крб.); виділення для ремонту житла і надвірних споруд сім'ям загиблих 15 м $^{3}$ лісоматеріалу та 90 листів шиферу, 3 м $^{3}$ лісоматеріалу та вісімдесяти 80 листів шиферу, 100 листів шиферу відповідно. Окрім цього, парткомітети звітували про виділення сім'ям загиблих воїнів коштів для виготовлення та встановлення пам'ятників, надмогильних плит ${ }^{14}$.

Такі ж відомості зустрічаємо й у «звітах» міських і районних комітетів Львівського обкому, що подавались на «усні запити» обласного партійного осередку.

Так, у матеріалах виокремлюємо житлове забезпечення «афганців» - виділення квартир для 8 осіб і поставлення на облік, а також «вирішення питання про виділення квартир» для 7 осіб і перебування 1 «афганця» у черзі на обмін квартири ${ }^{15}$; забезпечення автотранспортом - для 3 «афганців», оформлення документів на отримання автомобіля (1), поставлення на облік на придбання (1), придбання на пільговій основі (2), «відпущення поза чергою» (1), «вирішується питання» про придбання автомобіля з ручним керуванням (1), забезпечення 1 «афганця» кош-

\footnotetext{
13 Ibid. Арк. 36, 42, 50, 55.

14 Ibid. Арк. 4, 6, 8, 12, 15, 22, 25, 26, 28, 30, 31, 32, 34.

15 Державний архів Львівської області. Ф. 3. Оп. 53. Спр. 96. Арк. 1, 2, 10, 18, 32, 34, 42, 44, 47, 49, 60.
} 
тами на придбання бензину16; прикріплення до салону-магазину для «інвалідів війни і праці» (6 осіб), забезпечення продуктами підвищеного попиту (1 особу) ${ }^{17}$; оздоровлення - «вирішення питань» про виділення путівок на санаторне оздоровлення 3 осіб і направлення «афганця» на лікування до шпиталю для «інвалідів Великої Вітчизняної війни»18. Серед заходів з матеріально-побутового забезпечення «афганців» виокремлюємо «вирішення питання про виготовлення і встановлення металевого гаражу» (1), виділення місця під гаражне приміщення (1), поставлення на чергу для будівництва гаражу (1), забезпечення матеріалами для будівництва гаражу (1), забезпечення будматеріалами для будівництва господарського приміщення - 100 листів шиферу, 10 м³ лісоматеріалу, 5 т. цементу (1), заміна ванни, ремонт даху будинку (1) ${ }^{19}$.

Також виокремлюємо наступні напрямки підтримки сімей загиблих «афганців»: виділення квартир для дружин із дітьми загиблих воїнів, призначення пенсійного забезпечення «на дітей», а також виділення квартир сім'ям загиблих, батьки яких потребували покращення житлових умов (5 сімей) ${ }^{20}$; виділення сім'ям одноразової грошової допомоги (100-200-250 крб.) та коштів на виготовлення та установку пам'ятників, надгробних плит на могили загиблих «афганців»²1. Суми, котрі зафіксовані на виготовлення та встановлення пам'ятників, що виділялися сім'ям, становили 998-999-1000 крб. В одному випадку загиблому «афганцю» пам'ятник було встановлено за кошти бабусі та при грошовій допомозі (100 крб.) від райвиконкому 22.

Також мали місце випадки поставлення сім'ї на чергу для встановлення телефону, прикріплення сімей загиблих воїнів до магазину-салону для «інвалідів та учасників BВВ», «відпущення» без черги автомобіля для сім'ї загиблого «афганця», вручення грошової допомоги матері загиблого «афганця» від райкому та правління колгоспу (70 і 50 крб. відповідно); виділення путівки на оздоровлення для матері воїна 23 . Таким чином, сім'ям загиблих воїнів із Львівщини надавалася така ж матеріально-побутова допомога, як і «афганцям» Волині. Зокрема, представлена «звітність» про ремонт квартири матері загиблого воїна, виділення земельної ділянки та будматеріалів для будівництва житла, допомогу сім'ї у забезпеченні паливом і кормами для худоби, «вирішення питання» щодо допомоги сім'ї у придбанні будматеріалів (10 000 шт. цеглин і 3 т. вапна), виділення двом сім'ям 200 листів шиферу для перекриття даху та виділення вапна, 3 м³ «лісу», 70 шиферин, 10000 цеглин, 2 т. цементу відповідно 24.

Названі факти допомоги та заходи з покращення житлово-побутових умов вказаних категорій населення засвідчують напрями державної підтримки станом на 1984 р. Як свідчать джерела, матеріально-побутова допомога, яка кількісно різнилася, надавалась відповідно до потреб та оцінок відповідних комісій про які вказувалось вище. Адже зустрічаємо відомості партійних комітетів з формулюваннями

\footnotetext{
16 Ibid. Арк. 2, 12, 17, 37, 34, 42, 52, 53.

17 Ibid. Арк. 1, 12, 32, 34, 42, 46.

18 Ibid. Арк. 3, 12, 37, 47.

19 Ibid. Арк. 2, 13, 17, 18, 32, 56.

20 Ibid. Арк. 4, 5, 7, 8, 33, 38, 40, 56, 79.

21 Ibid. Арк. 3, 4, 5, 7, 8, 10, 13, 33, 37,39, 68, 70, 79.

22 Ibid. Арк. 43.

23 Ibid. Арк. 31, 39, 72, 80.

24 Ibid. Арк. 31, 42, 44, 59, 72, 80.
} 
про проживання сімей загиблих військовослужбовців у «задовільних» матеріально-побутових умовах, та які, наприклад, «не потребували будматеріалів», або - «не виявили потреби в установленні зв'язку». Щодо самих демобілізованих воїнів також мали місце випадки, коли, згідно «звітних» формулювань останні «житла не потребували», «щодо установки телефонів не звертались», на «розширення житла» та «покращення житлових умов» сім'ї (демобілізованих «афганців» - Aвт.) «не претендували», «прохань і заяв на адресу партійних, радянських, господарських органів не надходило» 25 .

Про вирішення питань щодо покращення умов життя, праці та побуту «афганців», що зазнали інвалідності, та сімей загиблих воїнів, як складової реалізації Постанови ЦК СРСР та уряду від 17 січня 1983 р. звітували й у Київській області. Зокрема, вказувалося про пенсійне забезпечення для 27 «афганців», котрим встановлено інвалідність, та для 9 сімей загиблих - «по втраті годувальника»; «план» видачі квартир на перший квартал 1985 р. для 4 сімей «афганців»; виділення автомобілів з ручним керуванням для 3 «афганців»; встановлення квартирних телефонів для 9 «афганців», перебування на черзі для телефонізації 4 осіб; проведення профілактичного медичного обстеження «інвалідів і поранених» - 7 «афганців» було госпіталізовано для стаціонарного лікування, забезпечення путівками на санаторно-курортне лікування для «тих, хто потребував»; закріплення «афганців» $\mathrm{i}$ сімей загиблих для індивідуального обслуговування до «магазинів та столівзамовлень»; установлення надгробків на могилах 60 похованих воїнів (для 6 загиблих надгробки перебували у стадії виготовлення) 26.

Комплексність щодо контролю над різними видами забезпечення «афганців» i сімей загиблих воїнів прослідковуємо вже з 1987 р. Про це, зокрема, свідчить перелік питань, котрий «спускався» з обкому й адресувався першим секретарям міських і районних партійних комітетів. Так, «форма», згідно якої повинні були заповнюватись дані щодо вказаних категорій осіб, містила наступні пункти: щодо кількості «афганців», які проживали в області (місті, районі); кількості «афганців», забезпечених пенсійними виплатами (по лінії Мінсоцзабезу та Міноборони); кількості осіб, що отримали квартири, і тих, що перебували на квартобліку від шести місяців до більше трирічного терміну (від 1980 р.); щодо наданої допомоги у будівництві та ремонті житла (від 1980 р.) та щодо кількості осіб, які таку допомогу ще потребували; щодо кількості тих, хто отримав у 1986 р. безвідсоткові позики на індивідуальне житлове будівництво; щодо кількості проживаючих у будинках без центрального опалення; кількості забезпечених паливом у 1986 р.; щодо кількості осіб, котрим встановлено телефони та чисельності черги на телефонізацію від шести місяців до трирічного терміну і більше; кількості прийнятих до садівничих кооперативів і чисельності осіб, що перебували у черзі на вступ до них (з 1980 р.); щодо осіб, що мають право на безкоштовне отримання транспорту, кількості забезпечених ним та щодо черги на отримання; щодо забезпечення санаторнокурортними путівками у 1986 р., чисельності не забезпечених путівками згідно періодичності оздоровлення та тих, хто отримав компенсацію за не використання путівки; щодо протезованих воїнів і тих, хто потребував протезування (з 1980 р.); щодо диспансерного обстеження та госпіталізації у 1986 р. та черги на госпіталіза-

\footnotetext{
25 ДАВО. Ф. 1. Оп. 17. Спр. 684. Арк. 6, 8, 15; ДАЛО. Ф. 3. Оп. 53. Спр. 96. Арк. 3, 17, 37, 50.

26 Державний архів Київської області. Ф. 5. Оп. 108. Спр. 193. Арк. 1-3.
} 
цію; щодо працевлаштованих демобілізованих «афганців» та обліку тих, що навчалися 27.

Окрім зазначеного, до переліку даних відносилися відомості щодо участі демобілізованих «афганців» у громадській роботі: обрання до складу Рад народних депутатів, партійних органів, комсомольських комітетів; залучення до проведення виховних заходів із молоддю; членство у «добровільних народних дружинах»; присвоєнні імен воїнів, котрі «особливо відзначились в ДРА», вулицям, площам, полям, школам, піонерським дружинам; зачислення загиблих воїнів до складу трудових колективів ${ }^{28}$.

Щодо сімей загиблих «афганців» контролю підлягали питання щодо пенсійного забезпечення, квартирного забезпечення, наданої допомоги у будівництві та ремонті житла, потреб сімей у будівництві або ремонті, забезпеченні паливом, встановленні надгробних пам'ятників загиблим в Афганістані синам, чоловікам. Відомості щодо вказаних категорій мали бути повідомлені до 15 березня 1987 p. ${ }^{29}$

Огляди матеріалів Вінницького та Волинського обкомів засвідчують такі ж форми звітності щодо даних про «солдат та офіцерів - «афганців» і сімей загиблих військовослужбовців ${ }^{30}$.

Інформація щодо виконання згаданої Постанови «Про пільги військовослужбовцям, працівникам і службовцям...» від 17 січня 1983 р. в УРСР зафіксована у повідомленні ЦК КПУ. Так, згідно джерела, станом на 20 березня 1987 р. в Україні проживало 59000 «афганців» (солдат та офіцерів), серед яких налічувалось 1687 інвалідів і 2677 сімей загиблих військовослужбовців, щодо яких партійними, комсомольськими, господарськими органами реалізовувались різні види соціального забезпечення, встановлені «пільги та переваги», задовольнялись «потреби та запити» 31 . Зокрема, йшлося про першочергове забезпечення «колишніх воїнів» житловою площею та позачергове забезпечення «афганців» - інвалідів І групи та вказувалось про виділення 3818 квартир, серед яких 802 квартири - «афганцям», котрим встановлено інвалідність, і 427 квартир - сім'ям загиблих воїнів. Близько 3,5 тисяч осіб отримали допомогу у будівництві та ремонті індивідуальних помешкань ${ }^{32}$. Також інформувалось про підвищення розмірів пенсійного забезпечення для інвалідів I та II груп, сімей загиблих воїнів, відповідно до Постанови ЦК КПРС та Ради Міністрів СРСР від 26 липня 1984 р. та про надання для «більше 400 інвалідів» матеріальної допомоги на суму 26,5 тисяч карбованців, серед яких 7,5 тисяч крб. - органами соціального забезпечення 33 . Згідно даних, 471 особі з інвалідністю було надано транспортні засоби (автомобілі); для 25-ти осіб «питання вирішувалось». Також вказувалось, що «потреби цієї категорії осіб в автотранспорті за готівковий розрахунок задовольнялись повністю»34.

Питання щодо перевірки виконання Постанови «партії та уряду» від 1983 р. та «ретельного вивчення стану справ на місцях» порушувались надалі. Зокрема, у

\footnotetext{
27 ДАКО. Ф. 5. Оп. 117. Спр. 227. Арк. 6-8.

28 Ibid. Акр. 9.

29 Ibid. Арк. 8.

30 Державний архів Вінницької області. Ф. П-136. Оп. 83. Спр. 167. Арк. 2-5; Державний архів Волинської області. Ф. 1 Оп. 24 Спр. 57. Арк. 31-139.

31 ЦДАГО України. Ф. 1. Оп. 25. Спр. 3196. Арк. 15.

32 Ibid. Арк. 16.

33 Ibidem.

34 Ibidem.
} 
серпні 1987 р. у Київському обкомі КПУ розглядався контроль владних структур щодо виконання постанов партії та уряду; роботи партійних, господарських, громадських організацій щодо підвищення уваги до «афганців» і сімей загиблих воїнів, задоволенні їх потреб (працевлаштування, навчання, шефство й ін.); залучення «афганців» до активної участі у громадському житті, увіковіченні пам'яті загиблих; заходів з покращення медичного обслуговування, організації диспансеризації та лікування, «більш повного забезпечення» санаторно-курортним-лікуванням інвалідів-«афганців»; прийняття виконкомами, органами торгівлі, Держагропрому, споживчої кооперації заходів «з більш повного задоволення потреб інвалідів, інших «воїнів-інтернаціоналістів» промисловими та продовольчими товарами; хід забезпечення «афганців» і сімей загиблих воїнів житлом; здійснення заходів з покращення телефонізації квартир; стан забезпечення інвалідів автотранспортом, закріплення їх за станціями автосервісу; роботи засобів масової інформації з висвітлення героїзму та мужності «афганців», трудової діяльності звільнених у запас 35 .

Разом з цим, подавались відомості, котрі ілюструють питання щодо забезпечення «афганців» і сімей загиблих воїнів у Київській області. Так, із 2414 «афганців», котрі проживали на її території з 1980 р., - 180 осіб отримали квартири (416 перебували на обліку); 270 осіб, котрі отримали поранення, користувались «пільговим обслуговуванням»; з 1980 р. було установлено 104 телефони - 119 осіб перебували в черзі на «телефонізацію»; 102 «афганці» отримували пенсії; 92 надана допомога у будівництві та ремонті житла (36 осіб такої допомоги ще потребували); осіб, що тримали безвідсоткові позики на індивідуальне житлове будівництво, згідно джерела, не було; 19 осіб було прийнято до садівничих кооперативів (11 перебували на черзі до вступу); 24 особи було забезпечено автотранспортом (15 осіб перебували на черзі на отримання транспорту); 80 осіб у 1986 р. було забезпечено санаторно-курортними путівками; 1 особа отримала компенсацію за невикористання путівки; 14 осіб було протезовано; 1494 особи пройшли диспансерне обстеження у 1986 р., 10 «афганців» - були госпіталізовані ${ }^{36}$. Щодо сімей загиблих воїнів подавались наступні цифри: із 88 таких сімей - пенсійне забезпечення закріплювалось за 31 сім'єю, 13 отримали квартири, для 17-ти - була надана допомога у будівництві або ремонті житла (ще 6 сімей потребували такої допомоги), 60 сімей загиблих «афганців», котрі проживали у будинках без центрального опалення, були забезпечені «паливом», 78 загиблим «афганцям» були встановлені надгробні пам'ятники ${ }^{37}$.

Отже, державна політика щодо воїнів-«афганців» і сімей загиблих військовослужбовців впродовж 1980-х рр. передбачала певні напрямки соціального забезпечення: покращення матеріально-побутових умов «афганців», що зазнали інвалідності, та сімей загиблих військовослужбовців (виділення житла, надання матеріальної допомоги у будівництві або ремонті житлових, господарських приміщень); забезпечення засобами пересування - виділення автотранспорту; телефонізацію помешкань; пенсійне забезпечення «афганців» з інвалідністю, членів родин загиблих воїнів, пенсійні виплати «на дітей» загиблих військових; медичне забезпечення - диспансеризацію, санаторно-курортне оздоровлення «афганців» з інвалідністю; прикріплення вказаних категорій осіб для продовольчого та побутового об-

\footnotetext{
35 Державний архів Київської області. Ф. 5. Оп. 117. Спр. 192. Арк. 13-14.

36 Ibid. Арк. 6-7.

37 Ibid. Арк. 8.
} 
слуговування до салонів-магазинів для «інвалідів Ввв», забезпечення паливом, матеріальну допомогу сім'ям загиблих «афганців» щодо встановлення надгробних пам'ятників воїнам.

Проаналізовані джерела засвідчують, комплексність щодо контролю реалізації державної політики стосовно соціального забезпечення вказаних категорій осіб прослідковується лише у 1987 р. Відтоді партійні (міські та районні) комітети КПУ зобов'язувалися формувати дані щодо забезпечення вказаних категорій осіб, включаючи встановлений перелік питань стосовно житлового, пенсійного, медичного забезпечення, права на безкоштовне отримання автотранспорту, телефонізації помешкань, забезпечення паливом, працевлаштування, навчання, участі «афганців» у суспільно-політичному житті, матеріальної допомоги у виготовленні та встановленні пам'ятників загиблим воїнам тощо.

Питання соціального забезпечення воїнів-«афганців» і сімей загиблих військовослужбовців упродовж 1980-х рр. є багатоаспектним, тому потребує подальших дослідницьких пошуків, узагальнень, систематизації.

\section{REFERENCES}

Bahmet, M. \& Soroka, S. (2006). Komsomol ta neformal'ni ob'iednannia Ukrainy v period «perebudovy» [Komsomol and informal associations of Ukraine in the period of «Perestroika»]. Politychnyi menedzhment, 5, 164-181 [in Ukrainian].

Chervonopyskyi, S.V. (2008). Politychni ta sotsialni naslidky dlia Ukrainy spetsoperatsii SRSR $v$ Afhanistani 1979-1989 rokiv i rol USVA v yikh podolanni [Political and Social Implications for Ukraine of USSR Special Operations in Afghanistan 1979-1989 and the Role of USM in Overcoming It]. Kyiv: «Medinform» [in Ukrainian].

Danilova, N.Yu. (2001). Voennosluzhashchie, voiny-internatsionalisty, veterany: dinamika pravovogo statusa [Military personnel, internationalist warriors, veterans: dynamics of legal status]. Sotsiologicheskie issledovaniia, 10, 77-84 [in Russian].

Levchuk, K.I. (2009). Hromads'ki orhanizatsii Ukrainy: stvorennia ta diial'nist' (1985-1996) [Public Organizations of Ukraine: Creation and Activity (1985-1996)]. Vinnytsia [in Ukrainian].

Levchuk, K. (2016). Stvorennia ta osnovni napriamky diialnosti Ukrainskoi spilky veteraniv Afhanistanu (1985-2000 rr.) [Creation and main activities of the Ukrainian Union of Afghan Veterans (19852000)]. Gileya: naukovyi visnyk, 105, 84-87 [in Ukrainian].

Kostiria, A.A. (2008). Istoriografiia, istochnikovedenie, bibliografiia spetsoperatsii SSSR v Afganistane (1979-1989 gg.) [Historiography, historical source study, bibliography of the Special Operation of the USSR in Afghanistan (1979-1989)]. Kyiv [in Russian].

Ostrovyk, D. (2018). Problemy adaptatsii voiniv-«afhantsiv» v umovak htransformatsiinykh protsesiv u radianskomu sotsiumi 1980-kh rr. [Problems of adaptation of «Afghans» soldiers in the context of transformation processes in the Soviet society of the 1980s]. Naukovi zapysky z ukrainskoi istorii, (44), 88-98 [in Ukrainian].

Ostrovyk, D. (2019) Transformatsiia derzhavnoi polityky radianskoi vlady shchodo voiniv-«afhantsiv» v Ukraini 1979-1991 rr. [Transformation of the State Policy of the Soviet Authority on the Warriers«Afghants» in Ukraine 1979-1991]. Viiskovo-istorychnyi merydian: elektronnyi naukovyi fakhovyi zhurnal, 1 (23), 150-170. Retrieved from https://vim.gov.ua/pages/_journal_files/23.05.2019/ pdf/VIM_23_2019-150-170.pdf [in Ukrainian].

Shynkarenko, I. (2010). Evoliutsiia sotsialnoho statusu voiniv-internatsionalistiv v ukrainskomu suspilstvi [The evolution of the social status of international warriors in Ukrainian society]. Abstracts of Papers: IV rehionalnoi naukovo-praktychnoi konferentsii "Filosofsko-pedahohichni aspekty formuvannia svidomosti tekhnichnoi intelihentsii» (pp. 187-193). Krasnoarmiisk [in Ukrainian]. 


\section{Dmytro Ostrovyk}

(Hryhorii Skovoroda University in Pereiaslav, Pereiaslav, Ukraine)

e-mail: dima_ostrovyk@ukr.net

ORCID: https://orcid.org/0000-0001-7435-7035

\section{Social Welfare for Afghan War Veterans and Families of Fallen Servicemen in Ukraine in the 1980s}

The components of social security for Afghan war veterans and the families of fallen servicemen and their implementation during the 1980s in the Ukrainian SSR are analyzed in the paper.

On the basis of archival materials, it is shown how the state support was provided for these groups of the society, and the types of social security and their practical implementation are described. The analyzed sources contain important material for studying the issues of regulation and implementation of the Soviet state policy towards Afghan war veterans and families of fallen servicemen.

In particular, in the first half of the 1980s, took place the CPU's district, city, and regional committees control of measures for improving the living conditions of Afghan war veterans who suffered disabilities and the families of fallen officers and men, their parents, wives, children (allocation of apartments, providing material assistance in housing reconstructions, building of utility constructions, installation of telephones in apartments), allocation of vehicles, granting of pensions, treatment and rehabilitation of Afghan war veterans, help in making and installation of tombstones for fallen servicemen.

Complexity in monitoring the enforcing of state policy on social welfare of the studied groups of the society can be found only in 1987. Since then, the party (city and district) committees of the CPU had to form data on the provision of these groups of the society, including a list concerning housing, pension and medical care, the right to receive free vehicles, installation of telephones, fuel, employment, education, participation of Afghan war veterans in social and political life, etc.

Keywords: public policy, social security, Afghan war veterans, families of the fallen 